\title{
Effects of irregular cropping on nutrient uptake and status of apple trees
}

\author{
Nagy, P.T. ${ }^{1}$, Szabó, Z. ${ }^{2}$, Soltész, M. \& Nyéki, J.² \\ ${ }^{1}$ Department of Agricultural Chemistry and Soil Science, University of Debrecen, Centre of Agricultural Sciences, \\ Faculty of Agronomy, Böszörményi u. 138. Debrecen, H-4032, Hungary, \\ ${ }^{2}$ Institute for Research and Development, University of Debrecen, Centre of Agricultural Sciences, Debrecen, \\ Hungary
}

\begin{abstract}
Summary: Produce of harmonic nutrient balance and status of trees is basic task of growers for qualified fruit growing. The role of crop loaded is essential to grow the productivity of trees without nutrient disorder or other nutritional problems. To reduce the frequency of biennial bearing there are some ways (site and species selection, crop regulation, irrigation, nutrition etc.) from them one is the best easy way the proper site and species oriented nutrition. Sometimes the responsible for irregular cropping is the insufficient fertilization. Observed irregular cropping at two apple cultivars (Malus domestica Borkh., cv. 'Summerred' and cv. 'Mutsu') in an integrated apple orchard at HajdúnánásTedej, in 2007 resulted a chance to determine nutritional status of "bearing" and "non bearing" trees and investigate the effects of irregular cropping on nutrient uptake and possibilities of correction. Our results pointed out that irregularity is connection on nutrition status of trees. Irregular cropping results in insufficient nutrient uptake and disharmony of nutrients. For this reason, the establishment of nutrient status of "non bearing" trees is could permit a chance to correct and improve the nutrient supply of trees which help to breakdown the vicious circle of irregularity.
\end{abstract}

Key words: cropping, nutrient, apple

\section{Introduction}

The phenomena and of course the problem of irregular cropping is perhaps as old as fruit growing itself. Biennial bearing, alternate bearing, alternate year cropping, irregular bearing or cropping, periodicity in cropping, are all synonymous terms which are different from the unfruitfulness and shy cropping (Singh, 1972). Various workers have tried to tackle this problem from different angels but so far without any significant success.

Occasionally, certain fruit trees, mostly apples bear heavily one year and sparsely the next. This is called "biennial bearing." In the last two decades, biennial bearing habit was founded at pear (Göndör \& Tóth, 1998), plum (Keulemans, 1990) and mango cultivars (Chacko, 1991) as well. The spring-flowering buds of most deciduous fruit trees have actually been formed during the previous summer. Therefore, an especially heavy crop one year may prevent adequate flower bud formation for the following year because the carbohydrates produced through photosynthesis are used preferentially for fruit production during the "on" year. Experimental evidence indicates that maturity of terminal shoots and accumulation of carbohydrate in the shoot apex are in some way associated with the synthesis of the floral stimulus, the absence of which can result in lack of flowering or biennial bearing in many mango cultivars (Chacko, 1991).

It is clear from many papers and researches published that the main reasons of biennial bearing are came from the biological backgrounds of cultivars (hormonal and genetic aspects). But it is also true that irregular bearing is strong connection with nutritional status and vigor of trees. With 'Golden Delicious' and 'Granny Smith', the incidence of biennial bearing increased as rootstock vigor increased, but with 'Redchief Delicious' biennial bearing declined as rootstock vigor increased (Barritt et al., 1997). The application of increasing amount of nitrogen increased both nitrogen level in leaves and flower bud initiation at young 'Red Delicious' trees. In biennial bearing 'Golden Delicious' a positive relationship has been established between leaf nitrogen and the 'off year' yield (Lalatta, 1980).

Rootstock and habit of trees has basic role in irregular bearing. Trees of 'Red Fuji' on Mark and MM.111 have shown little tendency towards biennial bearing, whereas on M.9, M.26 and MM.106 (particularly) 'Red Fuji' trees have had marked annual fluctuations in yield (James \& Middleton, 2001). Similar results obtained (Jadczuk et al., 1998) which indicated that type of root system plays an important role in growth and productivity of sour cherry trees. Roles of relation of shoot growth to bud initiation emphasized by 
Couranjou, 1968. Janssen, 1969 also pointed out that there is a negative correlation between the density of fruit setting (yield of crop respectively) and the fruit diameter of apples. A big crop gives small apples and vice versa. Furthermore there is a negative influence on the yields of the next year (biennial bearing) when the crop of this year exceeds a certain limit (biennial bearing limit). This limit depends on the individual situation of an orchard (apple varieties, soil conditions, micro-climate, intensity of cultivation etc.).

Biennial bearing of fruit trees is difficult to alter or correct. Moreover, cultivar's biennial bearing habit was often intensified unsatisfied nutritional conditions (Tukey, 1986).

Many authors pointed out that regulation of cropping (by several different methods) is the base to solve problems of irregular cropping (Lombard, 1982; Link, 1983; Helsen \& Deckers, 1984; Bower et al., 1990, Sergent et al., 1997; Tojnko et al., 2001). Hence, crop regulation is the most important measure to assure regular yields and optimal fruit quality (Widmer et al., 2006).

Moreover, it is very hard task to estimate the fruit failure which follows from biennial bearing, but its rate is growing continuously year by year all over the world. This finding is probably correlation with the growing rate of climatic anomalies. Hence, the aim of this paper is to provide further data about the phenomena of biennial bearing to get closer to the solving.

\section{Materials and methods}

In 2007 irregular cropping was observed at two apple cultivars (Malus domestica Borkh., cv. 'Summerred' and cv. 'Mutsu') in the integrated orchard of TEDEJ Rt., Hajdúnánás-Tedej, in Eastern Hungary.

The phenomenon of biennial bearing was appeared in small plots, regarded some trees in the rows. Based on orchard observation, investigation was carried out with these cultivars to study the effects of irregular cropping on nutrient uptake and status of trees.

Leaf samples were collected from "bearing" and "non bearing" trees simultaneously, at full bloom and later at the standard sampling time, according to Nagy et al. (2006).

The orchard was set up on lowland chernozem soil. It was established in the autumn of 1999, using grafted on MM106 rootstocks at a spacing of $3.8 \times 1.1 \mathrm{~m}$. The orchard has been treated according to the Integrated Fruit Production guidelines.

The orchard was irrigated. Soil samples were taken from three layers $(0-20 \mathrm{~cm} ; 20-40 \mathrm{~cm}$ and $40-60 \mathrm{~cm})$ of each plot, at the middle of the section by using manual soil sampling equipment. For the characterisation of the soil the most important soil parameters were determined. Sampling was performed at the beginning of the vegetation period on March, in 2008.

The soil samples were dried outdoors in an airy place in a $1-1.5 \mathrm{~cm}$ layer, then the soil was sieved through a sieve of $2 \mathrm{~mm}$ hole size, homogenized and stored in plastic boxes until the examination. For extracting the available phosphorus and potassium content of soils, ammoniumlactate extractant (so called AL soluble) was used. AL soluble phosphorus was quantified by colorimetrically with phospomolybdovanadate method, using a spectrophotometer (Metertech VIS SP-850 Plus; Metertech Inc., Taipei, Taiwan). The amount of potassium was quantified by flame atom emission spectrophotometry method using an Unicam SP90B Series 2 Atomic Absorption/Emission Spectrophotometer (PYE Unicam, England).

Mineralized nitrogen contents of soil samples were quantified according to Houba et al.,1986.

Soil $\mathrm{pH}, \mathrm{K}_{\mathrm{A}}, \mathrm{H} \%$ and $\mathrm{CaCO}_{3}$ content was determinated according to Hungarian standards (MSZ 20135:1999).

For extracting the available $\mathrm{Mg}$ content of soil $\mathrm{KCl}+$ EDTA extractant was used according to Hungarian soil laboratory guidelines (MSZ 20135:1999).

Soil available $\mathrm{Mg}$ was quantified by flame atomic absorption spectrophotometry, using a SpectrAA-10 Plus spectrophotometer (Varian Australia Pty Ltd. Mulgrave, Australia).

Leaf samples were dried outdoors in an airy place for a week. After drying samples in a well-ventilated drying oven at $70{ }^{\circ} \mathrm{C}$, the whole sampled material was finely grounded and homogenized. Samples were then stored in paper bags in a dark and dry place until use. Before measuring samples were put in desiccator to avoid rehydration.

Nitrogen content of plant samples was determined from homogenized samples directly using the dry combustion method according to Nagy 2000, using an Elementar Vario EL analyser (Elementar Analysensysteme GmbH, Hanau, Germany).

Plant phosphorus and potassium contents determine as follows: homogenized leaf samples ( $0.5 \mathrm{~g}$ each sample) were digested with cc. $5 \mathrm{ml} \mathrm{H}_{2} \mathrm{SO}_{4}$ and $5 \mathrm{ml} \mathrm{H}_{2} \mathrm{O}_{2}$ in a heating block digestor, at $220{ }^{\circ} \mathrm{C}$ until full digestion.

\section{Results and discussion}

\section{Soil analysis}

As biennial bearing limit depends on the individual situation of an orchard (varieties, soil conditions, microclimate, intensity of cultivation etc.) soil samples were taken to establish nutrient supply ability of soil and estimate soil conditions of orchard.

Obtained results of soil analysis are represented in Table 1.

The $\mathrm{pH}$ of soil was near the neutral value, slightly acidic. The physical category of soil was clay loam. The soil $\mathrm{P}$ and $\mathrm{K}$ was weak, while the soil $\mathrm{N}$ and $\mathrm{Mg}$ was adequate for fruit growing. Besides conventional soil testing procedures, $0.01 \mathrm{M} \mathrm{CaCl}_{2}$ was used to give further information about the easily soluble and available mineral $\mathrm{N}$ contents of soil.

From the easily soluble $\mathrm{N}$ forms the nitrate was dominant. Measured values correspond to the type of examined soil and decreased by depth. The micronutrient contents of soil (data not showed) were medium. 
Table 1. Results of soil analysis

\begin{tabular}{|l|c|c|c|c|}
\hline \multirow{2}{*}{ Parameters } & \multicolumn{4}{c|}{ Depth $(\mathrm{cm})$} \\
\cline { 2 - 5 } & $0-20$ & $20-40$ & $40-60$ & $0-60$ \\
\hline $\mathrm{Humusz} \%$ & 2.75 & 2.23 & 2.05 & 2.34 \\
\hline $\mathrm{KA}$ & & & & 43 \\
\hline $\mathrm{pH}(\mathrm{KCl})$ & 6.46 & 6.24 & 6.31 & 6.34 \\
\hline $\mathrm{CaCO} 3(\%)$ & $<0.1$ & $<0.1$ & 0.5 & 0.5 \\
\hline $\mathrm{P}_{2} \mathrm{O}_{5}(\mathrm{mg} / \mathrm{kg})(\mathrm{AL})$ & 164.11 & 89.12 & 42.7 & 98.64 \\
\hline $\mathrm{K}_{2} \mathrm{O}(\mathrm{mg} / \mathrm{kg})(\mathrm{AL})$ & 250.44 & 160.69 & 98.65 & 169.93 \\
\hline $\mathrm{NO}_{3}^{-}-\mathrm{N}(\mathrm{mg} / \mathrm{kg})\left(0.01 \mathrm{M} \mathrm{CaCl}_{2}\right)$ & 13.05 & 8.29 & 5.25 & 8.86 \\
\hline $\mathrm{NH}_{4}^{+}-\mathrm{N}(\mathrm{mg} / \mathrm{kg})\left(0.01 \mathrm{M} \mathrm{CaCl}_{2}\right)$ & 1.05 & 0.76 & 0.19 & 0.67 \\
\hline $\mathrm{Mg}^{*}(\mathrm{mg} / \mathrm{kg})\left(0.01 \mathrm{M} \mathrm{CaCl}_{2}\right)$ & 188 & 164 & 155 & 169 \\
\hline
\end{tabular}

Table 2. Results of leaf analysis (2007)

\begin{tabular}{|l|c|c|c|c|}
\hline & \multicolumn{2}{|c|}{$20 / 04 / 2007$} & \multicolumn{2}{c|}{$01 / 08 / 2007$} \\
\hline & \multicolumn{2}{|c|}{ 'Summered' } & \multicolumn{2}{c|}{ 'Summerred' } \\
\hline & Bearing & Non bearing & Bearing & Non bearing \\
\hline N (\% d.m.) & 3.46 & 3.04 & 1.70 & 1.69 \\
\hline P (\% d.m.) & 0.18 & 0.14 & 0.18 & 0.12 \\
\hline K (\% d.m.) & 1.24 & 1.19 & 1.84 & 1.61 \\
\hline & \multicolumn{2}{|c|}{$20 / 04 / 2007$} & \multicolumn{2}{c|}{$01 / 08 / 2007$} \\
\hline & \multicolumn{2}{|c|}{ 'Mutsu' Butsu' } \\
\hline & Bearing & Non bearing & Bearing & Non bearing \\
\hline N (\% d.m.) & 3.13 & 2.44 & 2.25 & 2.04 \\
\hline P (\% d.m.) & 0.24 & 0.17 & 0.24 & 0.22 \\
\hline K (\% d.m.) & 1.43 & 1.22 & 1.61 & 1.40 \\
\hline
\end{tabular}

Table 3. Results of leaf analysis (2008)

\begin{tabular}{|l|c|c|c|c|}
\hline & \multicolumn{2}{|c|}{$26 / 04 / 2008$} & \multicolumn{2}{c|}{$31 / 07 / 2008$} \\
\hline & \multicolumn{2}{|c|}{ 'Summerred' } & \multicolumn{2}{c|}{ 'Summerred' } \\
\hline & Bearing & Non bearing & Bearing & Non bearing \\
\hline N (\% d.m.) & 4.01 & 4.31 & 2.36 & 2.67 \\
\hline P (\% d.m.) & 0.20 & 0.20 & 0.13 & 0.15 \\
\hline K (\% d.m.) & 1.05 & 1.17 & 1.31 & 1.04 \\
\hline & \multicolumn{2}{|c|}{$26 / 04 / 2008$} & \multicolumn{2}{c|}{$31 / 07 / 2008$} \\
\hline & \multicolumn{2}{|c|}{ 'Mutsu' } & Bearing & Non bearing \\
\hline & Bearing & Non bearing & 2.30 & 2.48 \\
\hline N (\% d.m.) & 3.66 & 3,84 & 0.15 & 0.19 \\
\hline P (\% d.m.) & 0.22 & 0.18 & 1.36 & 1.47 \\
\hline K (\% d.m.) & 1.05 & 1.17 & &
\end{tabular}

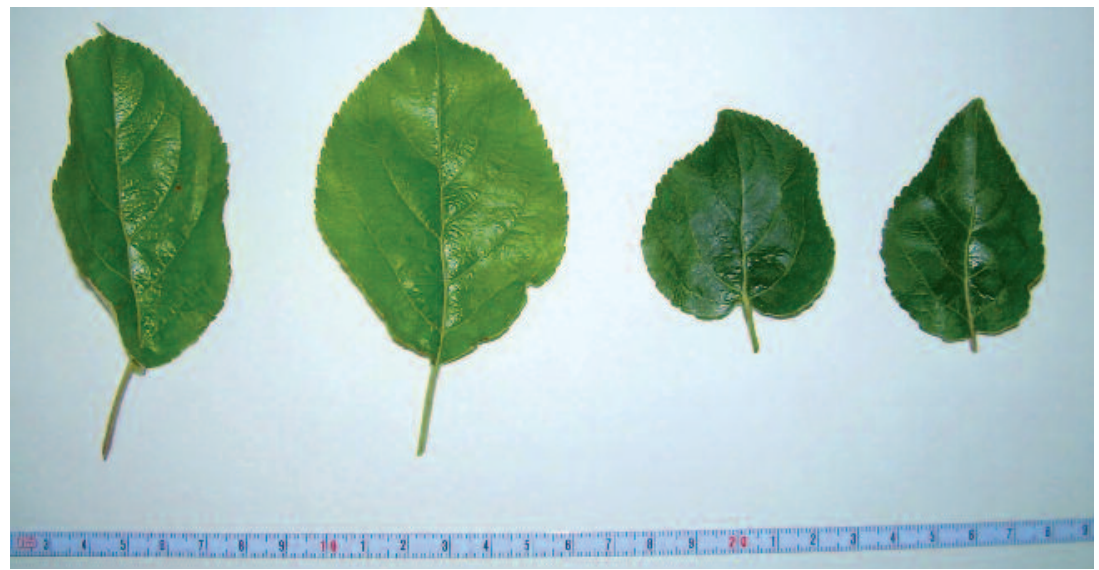

Figure 1. Leaves of "Non bearing" 'Summerred' trees (left) and "Bearing" 'Summerred' trees (right)

\section{Leaf analysis}

Results of leaf analysis were showed in Table 2-3. Leaves of non bearing trees contained lower nitrogen, phosphorus and potassium in 2007 (Table 2). This result is similarly to those published by Faust, 1989; Buwalda and Lenz, 1992 and Sadowski et al., 1995.

Leaves collected at full bloom from "non bearing" trees contained lower phosphorous but higher nitrogen and potassium in 2008 . Later, "non bearing" leaves collected at standard sampling date contained higher nitrogen and phosphorous than "bearing" trees.

Leaf potassium was changed contrary, depended on cultivars. $\mathrm{K}$ was higher in leaves of "non bearing" 'Mutsu' trees but lower in leaves of "non bearing" "Summerred' trees (Table 3). It is confirmed that earlier finding that the absence of fruit has not consequent effect on leaf K (Sadowski et al., 1995).

Leaf $\mathrm{N}$ and $\mathrm{P}$ of "bearing" and "non bearing" trees showed reversed tendency in 2007 and 2008. It explained by the shifted vegetative-generative balance of trees, affected the irregular cropping. In "off" year the vegetative processes become dominant, the trees are more vigorous than in "on" year. Leaves of "non bearing" trees (left) are larger and well developed than leaves of "bearing" trees (Figure 1). Shoot growing is more intensive and the foliage is more developed at "non bearing" trees. The lack of generative organ resulted disturbance in nutrient uptake also.

\section{Conclusion}

Our results pointed out that irregularity is connection on nutrition status of trees. Irregular cropping results in insufficient nutrient uptake and disharmony of nutrients. For this reason, the establishment of nutrient status of "non bearing" trees is could permit a chance to correct and improve the nutrient supply of trees which help to breakdown the vicious circle of irregularity. Timely observation of effects of "biennial bearing" on nutrient uptake (e.g. crop loaded of trees, continuously establishment of nutrient status of tree) is growing the chance of adequate intervene and early correction. 


\section{References}

Barritt, B.H., Konishi, B.S. \& Dilley, M.A. (1997): Tree size, yield and biennial bearing relationships with 40 apple rootstocks and three scion cultivars. Acta Hort., 451: 105-112.

Bower, J.P., Cutting, J.G.M., Lovatt, C.J. \& Blanke, M.M. (1990): Interaction of plant growth regulator and carbohydrate in flowering and fruit set. Acta Hort., 275: 425-434.

Buwalda, J. G. \& Lenz, F. (1992): Effects of cropping, nutrition and water supply on accumulation and distribution of biomass and nutrients for apple trees on 'M9' root systems. Physiologia Plantarum, 84: 21-28.

Chacko, E.K. (1991): Mango flowering - still an enigma! Acta Hort., 291: 12-21.

Couranjou, J. (1968): Shoot growth of green gage plum in relation with phases of biennial bearing. Acta Hort., 10: 241-252

Faust, M. (1989): Physiology of temperate zone fruit trees. John Wiley \& Sons, Inc. USA

Göndör, M. \& Tóth, M. G. (1998): Evaluation of frost resistance and productivity of pear cultivars in Hungary. Acta Hort., 484: 79-84.

Helsen, J. \& Deckers, J.C. (1984): Fruit set and growth reactions of pear trees, cv. Doyenne du comice on quince a, pruned at different ratios of vegetative on generative buds. Acta Hort., 149: 145-152.

Houba, V. J. G., Novozamsky, I., Huijbregts, A.W.M. \& Van Der Lee, J. J. (1986): Comparison of soil extrctions by $0.01 \mathrm{CaCl}_{2}$ by EUF and by some conventional extraction procedures. Plant and Soil, 96: 433-437.

Jadczuk, E., Sadowski, A. \& Stepniewska, M. (1998): Growth and yield of 'Schattenmorelle' cherry trees in relation to the type of root system. Acta Hort., 468: 385-392.

James, P.A. \& Middleton, S.G. (2001): Apple cultivar and rootstock performance at lenswood, South Australia. Acta Hort., 557: 69-76.

Janssen, H. (1969): Fruit thinning and market price of golden delicious and Cox's orange pippin production. Acta Hort., 13:152-169
Keulemans, J. (1990): Cropping behaviour, flowerbud formation, pollination and fruit set of different plum cultivars in Belgium. Acta Hort., 283: 117-130.

Lalatta, F. (1980): Leaf analysis of peach and apple trees in italy (Summary). Acta Hort., 92: 365-365.

Link, H. (1983): Regulation of growth and cropping of apple trees by cultural practices and chemical means. Acta Hort., 137: 269-276

Lombard, P.B. (1982): Special considerations in orchard design, training and pruning systems for pear trees. Acta Hort., 124: 171-176.

Nagy, P.T. (2000): Application of an element analyser for soil and plant analyses (dry combustion method). Agrokémia és Talajtan, 49: 521-534. (in Hungarian with English summary)

Nagy, P. T., Gonda, I., Dremák, P. \& Holb, I. (2006): Study on the micronutrient content of soil and leaf of an organic apple orchard in Eastern Hungary. International Journal of Horticultural Science, 12. (3): 7-12.

Sadowski, A., Kepka, M., Lenz, F. \& Engel, G. (1995): Effect of fruit load on leaf nutrient content of apple trees. Acta Hort., 383: 67-72.

Sergent, E., Ferrari, D. \& Leal, F. (1997): Effects of potasium nitrate and paclobutrazol on flowering induction and yield of mango (Mangifera indica L.) cv. Haden. Acta Hort., 455: 180-187.

Singh, L.B. (1972): Session V. Bearing behaviour in mango biennial bearing in mango - retrospect and prospect. Acta Hort. 24: 145-148.

Tojnko, S., Cmelik, Z. \& Zadravec, P. (2001): Influence of fertigation with nitrogen on leaf mineral element composition and cropping of 'Jonagold' and 'Golden delicious' apple trees. Acta Hort., 564: 379-385.

Tukey, L.D. (1986): Cropping characteristics of bearing apple trees annually sprayed with Paclobutrazol (PP333). Acta Hort., 179: 481-488.

Widmer, A., Stadler, W. \& Krebs, C. (2006): Effect of foliar applications of urea and boron on Malus Domestica and Pyrus Communis. Acta Hort., 721: 227-234. 